\title{
Relation between Hyperbilirubinemia and Urinary Tract Infections in the Neonatal Period
}

\author{
Belde Kasap ${ }^{1 *}$, Alper Soylu² and Salih Kavukçu² \\ ${ }^{1}$ Department of Pediatric Nephrology, Gaziantep Children's Hospital, Gaziantep, Turkey \\ ${ }^{2}$ Dokuz Eylul University, Department of Pediatrics, Division of Pediatric Nephrology, Izmir, Turkey
}

\begin{abstract}
Jaundice is a frequently encountered problem in the neonatal period. It may be associated with hemolytic, enzymatic, metabolic, endocrine disorders or infections. Recently it has been thought to be one of the clinical signs of urinary tract infections (UTIs) in the neonatal period. Although they are concurrently observed, the association between neonatal jaundice and UTI is still unidentified. Common belief is that the bilirubin levels rise as a result of UTIs and jaundice may be considered as an important clinical sign in that period. However, there is no strong recommendation for screening UTI in all neonates with jaundice. It is only recommended to screen for UTI in neonates with prolonged hyperbilirubinemia and direct bilirubinemia. On the other hand, there are conflicting data on the protective effects of bilirubin on renal tissue. In this review, all those questionable topics were discussed in the light of clinical and experimental studies.
\end{abstract}

Keywords: Urinary tract infections; Neonatal period; Hyperbilirubinemia

\section{Introduction}

Neonatal jaundice is rarely a pathological problem in the newborn period and it is encountered in $60 \%$ of the babies [1,2]. A very few of these babies have underlying hemolytic disease, metabolic or endocrine disorders, enzymatic deficiencies of liver, bacteremia or sepsis [1-3]. However, jaundice, which is the clinical manifestation of hyperbilirubinemia, may be the first sign of neonatal Urinary Tract Infections (UTIs). The decreased uroepithelial bactericidal activity, low levels of local immunoglobulin A, low urinary acidification capacity, and high periurethral colonization in the neonatal period lead to increased susceptibility to UTI [4]. However, diagnosing UTI is difficult in this period because of the non-specific symptoms including fever, irritability, vomiting, feeding refusal, diarrhea, failure to thrive, irritability, lethargy, oliguria or polyuria, malodorous urine and jaundice $[5,6]$. Thus, jaundice may be considered as one of the initial symptoms related to UTIs in newborns.

\section{What is the Importance of Jaundice in Diagnosing UTI in the Neonatal Period?}

The association between unexplained neonatal jaundice and UTI is well known $[3,7,8]$. The incidence of UTI in asymptomatic, a febrile and jaundiced infants was 5.5\% in 217 patients [9], 5.8\% in 400 patients with a mean age of 10 days [10], 6\% in 100 neonates between 2 to 4 weeks of age [8], $7.5 \%$ in 160 patients younger than eight weeks [7], $7.8 \%$ in 102 neonates younger than two weeks [3], 12.5\% in 120 neonates younger than four weeks [11], 18\% in 104 neonates between 4 and 14 days of age [12], and $21 \% 152$ neonates younger than four weeks [13] (Table 1). UTI was found in $6.5 \%$ of 462 jaundiced neonates, ages ranging from 3 to 25 days, $68 \%$ of whom were asymptomatic and a febrile [5].The only study with a control group among these studies was that performed by Shahian et al. [11]. In that study, incidence of UTI was $12.5 \%$ in 120 asymptomatic jaundiced neonates vs. none in 122 healthy neonates younger than four weeks [11].

Although methods for obtaining urine specimen and the threshold values to accept the results compatible with UTI differ among the aforementioned series in asymptomatic and afebrile infants, the incidence of UTI is much higher than those of the febrile infants younger than eight weeks which was reported as 5-11\% [14-16]. Thus, jaundice may be considered as important as fever in diagnosing UTI in the neonatal period.

In those series, up to $55 \%$ of the jaundiced infants were found to have urinary tract abnormalities (Table 1). The susceptibility of UTI increases in patients with urinary tract abnormalities and hyperbilirubinemia is thought to occur as a result of UTI [7]. Cleper et al. [17], found that the risk of jaundice was three times more likely in patients with vesicoureteral reflux during a UTI.

\section{Is UTI Associated with Early or Late Neonatal Hyperbilirubinemia?}

UTI has been accused as one of the reasons for prolonged (which persists after the second week in term infants and third week in premature infants) neonatal jaundice and a routine screening for UTI has been recommended in these infants $[3,7,8,10]$. Garcia and Nager [7] observed that the incidence of UTI was especially higher in infants who had jaundice after the postnatal eighth day. In another study conducted by Ghaemi et al. [10], the rate of UTI in patients with prolonged jaundice was similar to that of the febrile cases of similar age [8], and therefore assessing routine urinalysis and urine culture were recommended in patients with prolonged jaundice. On the other hand, Omar et al. [13] found that in jaundiced and otherwise asymptomatic neonates with UTI, jaundice emerged before the eighth day and Bilgen et al. [3] found that it emerged before the seventh day in the majority of cases. Thus, they suggested the urinalysis be included in the diagnostic routine studies of otherwise asymptomatic jaundiced newborns without an unknown etiology in the early neonatal period. In addition, Garcia and Nager [7] also stated that all asymptomatic infants with

*Corresponding author: Belde Kasap, Gaziantep Children's Hospital, Department of Pediatric Nephrology, Gaziantep, Turkey, Tel: +90 53250346 75; E-mail: beldekasap@gmail.com

Received February 10, 2014; Accepted March 27, 2014; Published March 31, 2014

Citation: Kasap B, Soylu A, Kavukçu S (2014) Relation between Hyperbilirubinemia and Urinary Tract Infections in the Neonatal Period. J Nephrol Therapeutic S11: 009. doi:10.4172/2161-0959.S11-009

Copyright: $\odot 2014$ Kasap B, et al. This is an open-access article distributed under the terms of the Creative Commons Attribution License, which permits unrestricted use, distribution, and reproduction in any medium, provided the original author and source are credited. 


\begin{tabular}{|c|c|c|c|c|c|c|c|c|c|}
\hline & $\begin{array}{c}\text { Garcia et al. } \\
{[7]}\end{array}$ & $\begin{array}{c}\text { Bilgen et al. } \\
{[3]}\end{array}$ & $\begin{array}{c}\text { Pashapour et al. } \\
{[8]}\end{array}$ & $\begin{array}{c}\text { Ghaemi et al. } \\
{[10]}\end{array}$ & $\begin{array}{c}\text { Xinias et al. } \\
{[5]}\end{array}$ & $\begin{array}{c}\text { Chen et al. } \\
\text { [9] }\end{array}$ & $\begin{array}{c}\text { Omar et al. } \\
\text { [13] }\end{array}$ & $\begin{array}{c}\text { Shahian et al. } \\
{[11]}\end{array}$ & $\begin{array}{c}\text { Mutlu et al. } \\
\text { [12] }\end{array}$ \\
\hline Age & $<8$ weeks & $<2$ weeks & 2-4 weeks & $\sim 10$ days & 3-25 days & $<8$ weeks & $<4$ weeks & $<4$ weeks & 4-14 days \\
\hline No of patients & 160 & 102 & 100 & 400 & 462 & 217 & 152 & 120 & 104 \\
\hline Patients with UTI & $12(7.5 \%)$ & $8(7.8 \%)$ & $6(6 \%)$ & $23(5.8 \%)$ & $30(6.5 \%)$ & $12(5.5 \%)$ & $32(21 \%)$ & $15(12.5 \%)$ & $19(18 \%)$ \\
\hline $\begin{array}{l}\text { Urine collection } \\
\text { method }\end{array}$ & Catheter & Catheter & $\begin{array}{l}\text { Suprapubic } \\
\text { aspiration }\end{array}$ & $\begin{array}{l}\text { Suprapubic } \\
\text { aspiration }\end{array}$ & $\begin{array}{l}\text { Suprapubic } \\
\text { aspiration }\end{array}$ & $\begin{array}{c}\text { Suprapubic } \\
\text { aspiration + } \\
\text { catheter + } \\
\text { urine bag }\end{array}$ & $\begin{array}{l}\text { } \text { : Catheter } \\
\text { : Urine bag }\end{array}$ & Catheter & Catheter \\
\hline $\begin{array}{l}\text { Patients with } \\
\text { urinary tract } \\
\text { abnormalities } \\
\text { in US }\end{array}$ & $6(55 \%)^{*}$ & $3(37.5 \%)$ & $1(16.6 \%)$ & $4(17.4 \%)$ & $5(16.6 \%)$ & $?$ & $7(4.6 \%)$ & $3(20 \%)$ & $5(26 \%)$ \\
\hline $\begin{array}{l}\text { (+) finding in } \\
\text { ultrasonography }\end{array}$ & $\begin{array}{l}\text { HN: } 3 \\
\text { PE: } 2 \\
\text { Stone: } 1\end{array}$ & $\begin{array}{l}\text { HN: } 1 \\
\text { PE: } 2\end{array}$ & $\begin{array}{l}\text { HN: } 0 \\
\text { PE: } 0\end{array}$ & $\begin{array}{l}\text { HN: ? } \\
\text { PE: ? }\end{array}$ & $\begin{array}{l}\text { HN: } 1 \\
\text { PE: } 2\end{array}$ & $?$ & PE: 7 & $\mathrm{HN}: 3$ & $\begin{array}{l}\mathrm{HN}: 1 \\
\mathrm{PE}: 4\end{array}$ \\
\hline VUR & $0^{* *}$ & $\begin{array}{c}1(12.5 \%) \\
\text { Grade III-IV (U) }\end{array}$ & $\begin{array}{c}1(16.6 \%) \\
\text { Grade III-IV (U) }\end{array}$ & $\begin{array}{l}1 \\
?\end{array}$ & $\begin{array}{c}5(16.6 \%) \\
\text { Grade II (U): } 2 \\
\text { Grade III (U): } 2 \\
\text { Grade IV (B): } 1\end{array}$ & $?$ & $0^{* * \star *}$ & 0 & $\begin{array}{c}2(1 \%) \\
\text { Grade III-IV (U):1 } \\
\text { Grade V(B) + PUV: } 1\end{array}$ \\
\hline $\begin{array}{l}(+) \text { finding on } \\
\text { scintigraphy }\end{array}$ & - & $0^{* \star *}$ & $1(16.6 \%)$ & - & $14(46.7 \%)$ & $?$ & - & - & $1(5 \%)$ \\
\hline $\begin{array}{l}\text { Timing of } \\
\text { scintigraphy }\end{array}$ & - & $3^{\text {rd }}$ month & $?$ & - & Acute phase (?) & $?$ & - & - & Acute phase (?) \\
\hline
\end{tabular}

UTI: urinary tract infection, US: Ultrasonography, VUR: vesicoureteral reflux, HN: hydronephrosis, PE: pelviectasis, U: unilateral, B: bilateral

\#: $32 \%$ of the patients were symptomatic.

*: Ultrasonography was performed in 11 of 12 patients.

**: Voiding cystourethrogram was performed in 4 of 6 patients.

***: Scintigraphy was performed in 7 of 8 patients.

****: Voiding cystourethrogram was performed in 12 of 32 patients.

Table 1: Clinical studies on asymptomatic and afebrile jaundiced infants

jaundice should be evaluated for UTI. However, Maisels and Newman [18] implied that, in this case, about 2.4 million babies per year should be catheterized, and this is expensive, invasive, and would be risky for the development of UTI and thus screening for UTI is only convenient for babies older than one week old.

\section{What do the Guidelines Recommend?}

Nonetheless, American Academy of Pediatrics (APA) guidelines recommend routine urine analysis neither in the early nor in the late neonatal period for hyperbilirubinemic neonates $[1,19]$. For instance, in 1994 APA guideline, screening for UTI was not recommended for late-onset hyperbilirubinemia [1]. In 2004 guideline, urinalysis was only recommended for babies with direct hyperbilirubinemia who were older than 35th gestational week [19]. Garcia and Nager [7] reported that the presence of UTI was more likely in patients with direct bilirubinemia, however, in most of the other studies, direct bilirubinemia was not observed in patients with UTI $[3,8,11,17,20,21]$. Consequently, common belief is that screening for UTI is needed in prolonged (indirect) hyperbilirubinemia and direct hyperbilirubinemia, and there is no such recommendation for jaundiced neonates in the early period.

\section{What is the Relationship between UTI and Hyperbilirubinemia?}

Despite these data showing their frequent coexistence, the relationship between UTI and hyperbilirubinemia has not been fully revealed yet $[7,8]$. Indirect hyperbilirubinemia associated with UTI was considered to be due to hemolysis caused by E. coli and other Gram (-) microorganisms [7]. Even slight hemolysis may increase the levels of serum bilirubin due to immature conjugation mechanisms in infants [7]. Thus, bilirubin levels may rise as an alerting sign even in clinically less severe UTIs. Direct hyperbilirubinemia associated with UTI may be due to cholestasis [7]. Although it is not exactly known how UTI may lead to cholestasis, microcirculatory disorders in the liver, direct bacterial products or endotoxin-induced mediators have been suggested as the cause [22,23]. Bilirubin is an endogenous molecule, which emerged as a result of reduction of heme molecule (Figure 1). Recently, attention has been focused on anti-oxidant and renoprotective effects of the substance [24,25]. Heme oxygenase-1 (HO-1), which catalyzes the first step of the reduction of the heme molecule may be induced by cytokines, enzymes, bacterial endotoxins, reactive oxygen species, ischemia/reperfusion injury (IRI) and hypoxia in mammals [26-28]. All these factors contribute to the pathogenesis of UTI, which causes renal injury [29]. Therefore, hyperbilirubinemia may be considered as a result of increased HO-1 enzyme activity during UTI.

\section{May High Levels of Bilirubin protect the Kidney?}

There are many studies evaluating the effects of bilirubin on renal tissue. Exogenous bilirubin was shown to be protective against IRI in the isolated perfused rat kidney [30]. Another study by the same team demonstrated that intravenous administration of bilirubin did not equally have the same protective effect and they thought that it was associated with a technical error about timing of removal of the kidney tissues [31]. In "Gunn rats", which are hyperbilirubinemic due to a genetic defect in uridine diphosphate glucuronyl transferase enzyme, thiobarbituric acid reactive substance levels were inversely correlated with serum bilirubin levels in the neonatal period, and this free radical resistance was considered to be provided by bilirubin [32] Also, kidneys of Gunn rats were protected as compared to Wistar rats in a cisplatin nephrotoxicity model [33]. In colestatic rats, in which cholestasis was induced by ligation of the common bile duct, glycerolinduced acute renal failure was prevented, and thus bilirubin was shown to be protective against renal IRI [34]. In another in vitro study on human proximal epithelial cells, it was reported that conjugated 


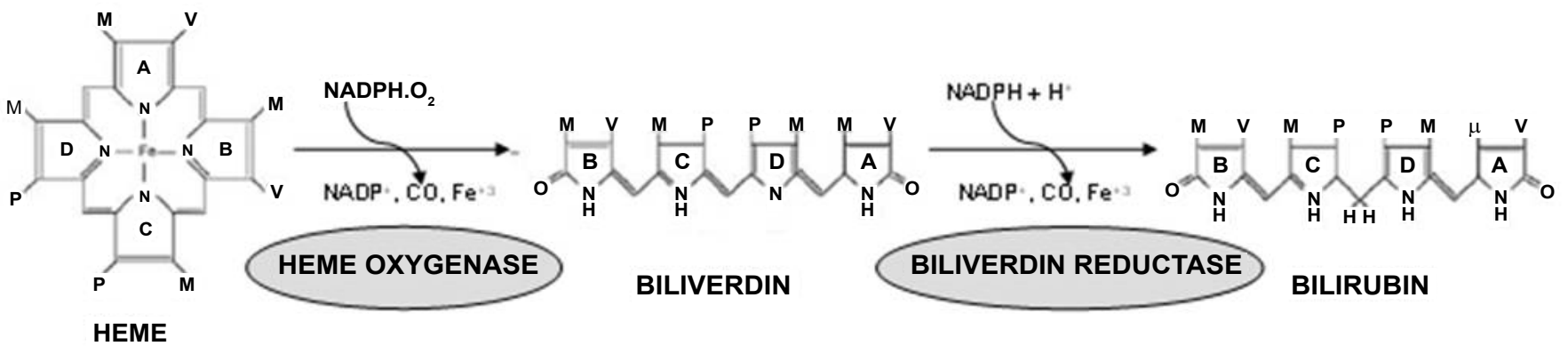

Figure 1: Degradation of heme molecule. The first step is the degradation of heme molecule into biliverdin via heme oxygenase (HO), which is the rate limiting enzyme. Subsequently, biliverdin is converted to bilirubin by biliverdin reductase.

bilirubin reduced the sensitivity of the cells to cisplatin and showed cytoprotective effects [35].

These data showing the renoprotective effects of bilirubin suggest that neonatal hyperbilirubinemia may play a protective role in preventing renal damage. The risk of renal injury varies inversely with age and patients of younger ages are known to be more susceptible to renal damage $[4,36]$. Diagnosing UTI in the neonatal period is difficult as patients are usually asymptomatic or show non-specific symptoms, and obtaining a proper sample of urine requires invasive procedures such as supra pubic aspiration or catheterization [5]. In addition, verifying renal parenchymal damage in the acute period with dimer captosuccinic acid (DMSA) is also difficult in this age group due to tubular immaturity. Thus, planning a clinical study comparing the effects of UTI in newborns with and without hyperbilirubinemia is difficult, and there has been no such study in the literature yet. To investigate this effect, we used exogenous bilirubin in rats with pyelonephritis and found that exogenous bilirubin in addition to antibiotics demonstrated positive effects on inflammation, fibrosis and apoptosis [37]. In a clinical study by Bilgen et al. [3], scintigraphic studies were made in seven of eight icteric neonates diagnosed with UTI at the third month and no pathological finding was found in any of them. However, in another study conducted by Xinias et al. [5], the bilirubin levels of neonates with positive cortical DMSA findings were significantly higher than those of with negative DMSA findings. These findings suggest that the patients with cortical damage have a higher amount of bacteremia and the severity of the infection lead to a more severe hemolysis. According to this study, it does not seem possible to conclude that bilirubin has protective effects of on renal damage.

\section{May Hyperbilirubinemia Lead to UTI?}

In our previous in vitro study investigating the effects of bilirubin on rabbit bladder and ureteral smooth muscle, hyperbilirubinemia was shown to cause dilatation, which may lead to urinary stasis and susceptibility to UTI [38]. However, in another study on hyperbilirubinemic newborns, no significant relation was found between bilirubin levels and pelvic diameters [39]. In addition, we could not demonstrate that the urine of hyperbilirubinemic newborns impede the growth of uropathogenic E. Coli in our recent study [40].

\section{Does Hyperbilirubinemia Associated with UTI have a Different Clinical Course?}

Omar et al. [13] found that the duration of phototherapy is shorter and exchange transfusion requirements were less likely in hyperbilirubinemic neonates with UTIs. This data suggested that neonatal hyperbilirubinemia associated with UTI leads to fewer complications.

In conclusion, newborn jaundice associated with UTI is related to increased levels of bilirubin due to the infection itself. This seems to be associated with increased HO-1 enzyme activity induced by endotoxins, cytokines, etc. UTI induced hyperbilirubinemia usually emerge in the form of prolonged jaundice and seems to have a more benign course. Although there is supporting data that increased levels of bilirubin have renoprotective effects, it is still controversial. As a result, neonatal jaundice associated with UTI may facilitate early detection of UTI rather than being a threat in terms of complications.

\section{Support or Financial Disclosure}

None.

\section{References}

1. [No authors listed] (1994)Practice parameter: management of hyperbilirubinemia in the healthy term newborn. American Academy of Pediatrics. Provisional Committee for Quality Improvement and Subcommittee on Hyperbilirubinemia. Pediatrics 94: 558-565.

2. Littlewood JM, Kite P, Kite BA (1969) Incidence of neonatal urinary tract infection. Arch Dis Child 44: 617-620.

3. Bilgen $\mathrm{H}$, Ozek E, Unver T, Biyikli N, Alpay H, et al. (2006) Urinary tract infection and hyperbilirubinemia. Turk J Pediatr 48: 51-55.

4. Chang SL, Shortliffe LD (2006) Pediatric urinary tract infections. Pediatr Clin North Am 53: 379-400, vi.

5. Xinias I, Demertzidou V, Mavroudi A, Kollios K, Kardaras P, et al. (2009) Bilirubin levels predict renal cortical changes in jaundiced neonates with urinary tract infection. World J Pediatr 5: 42-45.

6. Littlewood JM (1972) 66 infants with urinary tract infection in first month of life Arch Dis Child 47: 218-226.

7. Garcia FJ, Nager AL (2002) Jaundice as an early diagnostic sign of urinary tract infection in infancy. Pediatrics 109: 846-851.

8. Pashapour N, Nikibahksh AA, Golmohammadlou S (2007) Urinary tract infection in term neonates with prolonged jaundice. Urol $\mathrm{J}$ 4: 91-94.

9. Chen HT, Jeng MJ, Soong WJ, Yang CF, Tsao PC, et al. (2011) Hyperbilirubinemia with urinary tract infection in infants younger than eight weeks old. J Chin Med Assoc 74: 159-163.

10. Ghaemi S, Fesharaki RJ, Kelishadi R (2007) Late onset jaundice and urinary tract infection in neonates. Indian J Pediatr 74: 139-141.

11. Shahian M, Rashtian P, Kalani M (2012) Unexplained neonatal jaundice as an early diagnostic sign of urinary tract infection. Int $J$ Infect Dis 16: e487-490.

12. Mutlu M, Cayır Y, Aslan Y (2013) Urinary tract infections in neonates with jaundice in their first two weeks of life. World $\mathrm{J}$ Pediatr .

13. Omar C, Hamza S, Bassem AM, Mariam R (2011) Urinary tract infection and indirect hyperbilirubinemia in newborns. N Am J Med Sci 3: 544-547. 
Citation: Kasap B, Soylu A, Kavukçu S (2014) Relation between Hyperbilirubinemia and Urinary Tract Infections in the Neonatal Period. J Nephrol Therapeutic S11: 009. doi:10.4172/2161-0959.S11-009

Page 4 of 4

14. Crain EF, Gershel JC (1990) Urinary tract infections in febrile infants younger than 8 weeks of age. Pediatrics 86: 363-367.

15. Hoberman A, Chao HP, Keller DM, Hickey R, Davis HW, et al. (1993) Prevalence of urinary tract infection in febrile infants. J Pediatr 123: 17-23.

16. Hoberman A, Wald ER (1997) Urinary tract infections in young febrile children Pediatr Infect Dis J 16: 11-17.

17. Cleper R, Krause I, Eisenstein B, Davidovits M (2004) Prevalence of vesicoureteral reflux in neonatal urinary tract infection. Clin Pediatr (Phila) 43 : 619-625.

18. Maisels MJ, Newman TB (2003) Neonatal jaundice and urinary tract infections Pediatrics 112: 1213-1214

19. American Academy of Pediatrics Subcommittee on Hyperbilirubinemia (2004) Management of hyperbilirubinemia in the newborn infant 35 or more weeks of gestation. Pediatrics 114: 297-316.

20. Abourazzak S, Bouharrou A, Hida M (2013) [Jaundice and urinary tract infection in neonates: simple coincidence or real consequence?]. Arch Pediatr 20: 974-978.

21. Afzal N, Qadir M, Qureshi S, Ali R, Ahmed S, et al. (2012) Urinary tract infection presenting as jaundice in neonates. J Pak Med Assoc 62: 735-737.

22. Roelofsen H, Schoemaker B, Bakker C, Ottenhoff R, Jansen PL, et al. (1995) Impaired hepatocanalicular organic anion transport in endotoxemic rats. Am J Physiol 269: G427-434

23. Roelofsen $H$, van der Veere $C N$, Ottenhoff $R$, Schoemaker $B$, Jansen PL, et al. (1994) Decreased bilirubin transport in the perfused liver of endotoxemic rats. Gastroenterology 107: 1075-1084.

24. Marilena G (1997) New physiological importance of two classic residual products: carbon monoxide and bilirubin. Biochem Mol Med 61: 136-142.

25. Stocker R, Yamamoto Y, McDonagh AF, Glazer AN, Ames BN (1987) Bilirubin is an antioxidant of possible physiological importance. Science 235: 1043-1046.

26. Ostrow JD, Mukerjee P, Tiribelli C (1994) Structure and binding of unconjugated bilirubin: relevance for physiological and pathophysiological function. J Lipid Res 35: 1715-1737.

27. Ryter SW, Tyrrell RM (2000) The heme synthesis and degradation pathways: role in oxidant sensitivity. Heme oxygenase has both pro- and antioxidant properties. Free Radic Biol Med 28: 289-309.

28. Taillé C, El-Benna J, Lanone S, Dang MC, Ogier-Denis E, et al. (2004) Induction of heme oxygenase-1 inhibits $\mathrm{NAD}(\mathrm{P}) \mathrm{H}$ oxidase activity by down- regulating cytochrome b558 expression via the reduction of heme availability. $J$ Biol Chem 279: 28681-28688.

29. Sikorski EM, Hock T, Hill-Kapturczak N, Agarwal A (2004) The story so far: Molecular regulation of the heme oxygenase-1 gene in renal injury. Am $J$ Physiol Renal Physiol 286: F425-441.

30. Adin CA, Croker BP, Agarwal A (2005) Protective effects of exogenous bilirubin on ischemia-reperfusion injury in the isolated, perfused rat kidney. Am J Physio Renal Physiol 288: F778-784

31. Kirkby K, Baylis C, Agarwal A, Croker B, Archer L, et al. (2007) Intravenous bilirubin provides incomplete protection against renal ischemia-reperfusion injury in vivo. Am J Physiol Renal Physiol 292: F888-894.

32. Dennery PA, McDonagh AF, Spitz DR, Rodgers PA, Stevenson DK (1995) Hyperbilirubinemia results in reduced oxidative injury in neonatal Gunn rats exposed to hyperoxia. Free Radic Biol Med 19: 395-404.

33. Barabas K, Milner R, Farese J, Baylis C, Croker B, et al. (2008) Hyperbilirubinemia's protective effect against cisplatin nephrotoxicity in the Gunn rat. Anticancer Drugs 19: 495-502.

34. Leung N, Croatt AJ, Haggard JJ, Grande JP, Nath KA (2001) Acute cholestatic liver disease protects against glycerol-induced acute renal failure in the rat. Kidney Int 60: 1047-1057.

35. Nomura M, Matsunami T, Kobayashi K, Uchibayashi T, Koshida K, et al (2005) Involvement of ABC transporters in chemosensitivity of human renal cell carcinoma, and regulation of MRP2 expression by conjugated bilirubin. Anticancer Res 25: 2729-2735.

36. Smellie JM, Prescod NP, Shaw PJ, Risdon RA, Bryant TN (1998) Childhood reflux and urinary infection: a follow-up of 10-41 years in 226 adults. Pediatr Nephrol 12: 727-736

37. Kasap B, Soylu A, Ertoy Baydar D, Kiray M, TuÄŸyan K, et al. (2012) Protective effects of bilirubin in an experimental rat model of pyelonephritis. Urology 80 1389.

38. Murat N, Kasap B, Kavukcu S, Soylu A, Türkmen M, et al. (2006) In vitro analysis of the effect of hyperbilirubinemia on rabbit ureter and bladder. Pediatr Nephrol 21: 328-332.

39. Akil T, Avci M, Ozturk C, Akil I, Kavukcu S (2011) Is There Any Relationship between Hyperbilirubinemia and Pelvicaliceal Dilatation in Newborn Babies? Iran J Pediatr 21: 431-435.

40. Firinci F, Soylu A, Ozturk C, Gulay Z, Demir BK, et al. (2014) Hyperbilirubinemia and urinary tract infection: the effect of indirect hyperbilirubinemia on the in vitro growth of uropathogen Escherichia coli in newborn urine. Ren Fail 36: 55-57.
This article was originally published in a special issue, Pediatric Nephrology handled by Editor(s). Moazzam Hossain, Bangabandhu Sheikh Mujib Medica University, Bangladesh 